\title{
PUBLIC POLICY TOWARDS HIV MISCONCEPTIONS IN INDONESIA
}

(disubmit 05 November 2020, direvisi 01 Desember 2020, diterima 03 Desember 2020)

\author{
Agus Permadi ${ }^{1)}, \mathrm{Aji}^{2)}$ \\ ${ }^{1}$ University of Indonesia \\ Jl. Margonda Raya, Pondok Cina, Kecamatan Beji, Kota Depok, Jawa Barat 16424 \\ Corresponding Author: ajiaguspermadi@email.com \\ 2Bappeda Provinsi Banten \\ KP3B, Jl. Syech Nawawi Al Bantani, Serang, Banten
}

\begin{abstract}
This study focuses on HIV misconceptions in Indonesia. Based on Demographic and Health Surveys (DHS) Program, there are three common misconceptions about HIV: (1) whether HIV can be transmitted through mosquito bites, (2) whether transmission occurs by sharing food with a person who has HIVIAIDS, and (3) whether a healthy-looking person could have HIV. Using 2017 the Indonesia DHS, this study examines the impact of two factors - socio-demographic and media exposure - on HIV misconceptions in Indonesia. I found that respondents who belong to the younger age group, living in urban areas, have a higher degree of education, and have higher exposure to media were less likely to have misconceptions about HIV. This result indicates that to reduce HIV misconceptions in Indonesia, the government should make a targeted intervention program.
\end{abstract}

Keywords: HIV/AIDS; misconceptions, socio-demographic, media exposure, age, education, wealth

\section{INTRODUCTION}

This study examines the relationship between socio-demographic factors and media exposure with the three common HIV misconceptions. To eradicate HIV/AIDS, UNAIDS sets a target of 90-90-90. Whereby 2020, 90\% of all People Living with HIV (PLH) will know their HIV status, 90\% of PLH will receive antiretroviral (ARV) therapy and $90 \%$ of PLH who receive ARV therapy will have viral suppression (UNAIDS, 2014). However, the current situation in Indonesia is far from the UNAIDS targets, where only $51 \%$ of PLH know their status, and only $17 \%$ of
PLH take the ARV treatment. In other words, approximately $49 \%$ of people were living with HIV did not know their status. This condition is hazardous because these unaware people can transmit HIV to others in various ways. Besides, there were about $83 \%$ of PLH who already know their HIV status but did not uptake the treatment, which makes them more vulnerable from any diseases.

Other problems besides the low number of knowledge about HIV status and the small number of PLH who are taking ART treatment, are the negative stigma received by PLH from others even from medical staff who 
Jurnal Kebijakan Pembangunan Daerah, Vol. 4 No. 2 , Desember 2020, Hal. 109 - 117 p-ISSN: 2597-4971, e-ISSN: 2685-0079

are expected to have more knowledge about HIV. Examples of discrimination from medical workers against people with HIV/AIDS are, for instance, the reluctance of medical staff to touch PLH patients directly even though HIV will not be transmitted by only touching PLH patients directly. Moreover, in some cases, PLH is rejected by a Puskesmas (one of the health facilities in Indonesia). The reason is that there is no particular room, even though PLH does not need a special room at all.

Negative stigma and discrimination usually received by PLH due to a low level of comprehensive knowledge of HIV transmission and prevention. From the National Population and Family Planning Board (BKKBN), Statistics Indonesia (BPS), Ministry of Health (Kemenkes), 2017 report, it was found that only $15 \%$ of women and $16 \%$ of married men have a comprehensive knowledge of HIV transmission and prevention. The low level of comprehensive knowledge of HIV transmission and prevention is what ultimately encourages discriminatory behavior towards PLH. From the same source, it was reported that $35 \%$ of women and $29 \%$ said that a child with HIV could not go to school with those who are healthy. Though nothing will happen if a child is in school with a child who has HIV, besides, $64 \%$ of women and $54 \%$ of men will not want to buy vegetables from a PLH seller. Even though there has never been any evidence that shows that buying vegetables from someone who has HIV will transmit HIV to the buyer, this excessive fear must be ended. The government should take action to increase the level of comprehensive knowledge of HIV in Indonesia.

HIV awareness is not enough to succeed in the government's effort to fight against HIV. The government should think about how to increase the level of higher knowledge of HIV or comprehensive knowledge of HIV to prevent the negative stigma dan discrimination towards PLH. PLH is a sick person who needs our love and care rather than negative stigma and discrimination. They are facing a considerable challenge in their life at this moment; a better understanding of HIV will enable us to help them carefully. But on the contrary, if we lack knowledge, then our actions will tend to be harmful to them than help.

Mwamwenda (2014) argues that one of the bad effects of stigmatization was people discourage having HIV testing or HIV counseling because once they have proven to be HIV positive, they afraid they will receive negative stigma and also discrimination. In the Indonesian context, the very low percentage of people who detected his/her HIV status may also due to a similar reason. No one will have the incentive to know their situation when it means others will discriminate them in many ways. In some cases, a person who recently HIV positive gets fired from his company, while no proof working with HIV 
Jurnal Kebijakan Pembangunan Daerah, Vol. 4 No. 2 , Desember 2020, Hal. 109 - 117 p-ISSN: 2597-4971, e-ISSN: 2685-0079

positive person will transmit the disease to others.

Adi (2019) in The Jakarta Post reported that a public elementary school in Surakarta, Central Java, expelled 14 students identified as positive for HIV/AIDS amid protests from parents of other students. This case is one of the examples when people have inadequate knowledge regarding HIV, and they tend to react unproperly. There is no danger when our children have the same school with HIV positive children. People should understand more the way HIV transmits to prevent negative stigma and discrimination behavior. HIV indeed very dangerous, but a person with HIV is not.

The purpose of this research was to investigate the relationship between sociodemographic factors and media exposure with the three common HIV misconceptions. The socio-demographic factors in this research were age group, wealth index, type of residence, and educational attainment. The media exposure factors were frequency of reading newspapers or magazines, frequency of listening to the radio, frequency of watching television, and frequency of using the internet.

Previous studies have examined comprehensive knowledge of HIV, which include the misconceptions about HIV as dependent variables. Many of the studies have been conducted in Africa (Agüero \& Bharadwaj, 2014; Oginni et al., 2017; Ochako et al., 2011; \& Oljira et al., 2013). There are some conducted in South Asian countries such as Bangladesh and Nepal (Asaduzzaman et al., 2016 \& Khanal et al., 2013). However, to my knowledge, there has been no research that focuses on Indonesia. Therefore makes my study one of the first in the Indonesian context for these topics. For scholars who study this topic, investigating the case of Indonesia is important because of the differences in culture and religions. It would be interesting to examine whether the findings from other areas such as Africa are generalizable.

Also, with a large number of observations - approximately 59,000 from a large-scale nationally representative survey of individuals (Indonesian Demographic Health Survey, or IDHS) - the result of my study will be representative of the actual condition in Indonesia. With a large sample size, the point estimate will be more accurate, too. The data used also was the most updated IDHS data, which allow us to understand the current situation better.

\section{METHOD}

This study utilized the Indonesia Demographic and Health Surveys (IDHS) Data 2017, with the total number of respondents, were 59,149. The data widely used by scholars to investigate various topics, particularly the health and demographic issues. Individual-level data were used in this study to identify the relationship between the three common misconceptions of HIV with socio-demographic and media exposure 
factors. This data is very supportive because it has a large number of respondents who needed to conduct binary logistic regression.

The data analysis method in this study was binary logistic regression since the outcomes of the dependent variables were binary. Therefore, it will be less effective if we use linear regression, for example, since the dependent variables were not a continuous variable. The binary logistic regression method will be useful to predict the relationship between its dependent variables with the independent variables using the odds ratio. By interpreting the odds ratio, we can predict how the odds to know HIV misconception become more likely or less likely as a result of a change in independent variables.

\section{FINDINGS AND DISCUSSION}

This study found that the majority of the respondents having high misconceptions about HIV. The descriptive data surprisingly shows that $69.65 \%$ of respondents, or more than half of them, agreed that HIV could be transmitted by mosquito bites. Besides, $65.9 \%$ of respondents refused to share the foods with a person who has HIV. However, gladly, the percentage of respondents who did not know that a healthy-looking person can have HIV was quite low, with only $34.3 \%$. The high misconception regarding the first and second HIV misconceptions shows that the government should pay more attention to these two misconceptions than the third misconception.

Table 1. Number and Percentage of Respondents Knowledge about HIV Misconceptions

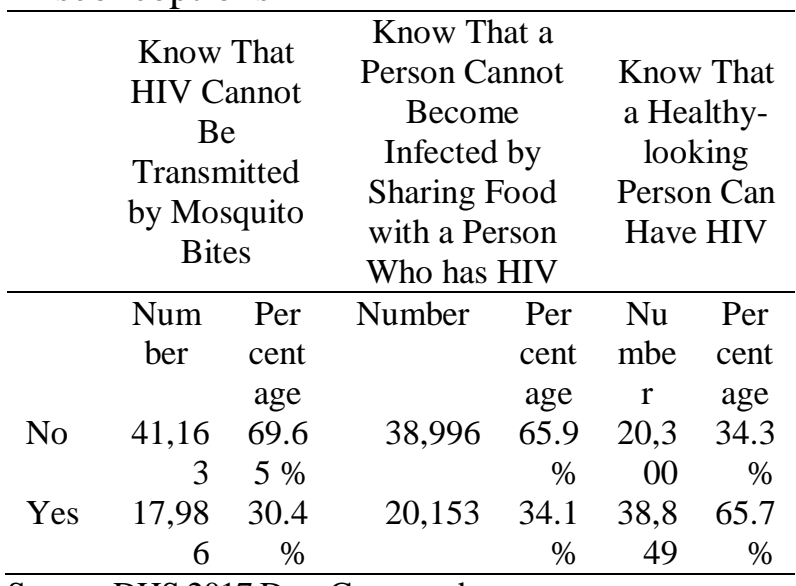

Source: DHS 2017 Data Computed

The high misconception about the first HIV misconception means that people can not differentiate between how HIV can be transmitted and how other diseases can be transmitted. If more people are afraid that HIV can be transmitted through mosquito bites, then they may refuse to live close to a person who has HIV. However, the low level of the first HIV misconception quite understandable since mosquito is a well-known spreader of many diseases like malaria. The high degree of misconception about the second HIV misconception means that many people will refuse to share the food with a person who has HIV. A person who has HIV will be isolated in the neighborhood because of this belief. Moreover, people might overreact by banishing a person who has HIV from their community. However, the high level of misconception regarding the second misconception is also quite understandable 
since it requires advanced knowledge about HIV. Finally, the third misconception was relatively low because it was relatively easier knowledge. Not only a person with HIV but also a person with any diseases will still look healthy.

Table 2. Association between HIV Misconception Knowledge with Sociodemographic and Media Exposure Factors

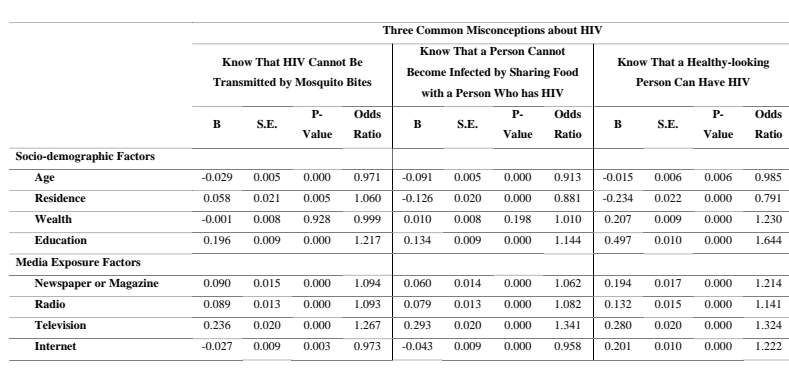

Source: Logit Regression Output DHS 2017

The age group. This independent variable was significantly correlated with the three HIV misconceptions, where the younger group of age were less likely to have misconceptions about HIV. For example, $71.3 \%$ of respondents from the youngest group of age know that a healthy-looking person can have HIV while only $52.2 \%$ from the oldest group of age know about that. These findings were different from the result of another study (Oginni et al., 2017), which revealed that the older groups of age were less likely to have a misconception about HIV. In the context of Indonesia, younger people could have a better comprehensive knowledge of HIV may due to the younger generation able to discuss HIV topics more open than the older generations. They talk in school, cafe, park, shopping center, or even online discussion. These young people also have a better penetration to multi-sources of media, especially the internet. By involving in an online forum, younger people have a better chance to improve their knowledge regarding HIV. Also, they can quickly get much information just by a single click in the browser. Younger people also may have a lower tendency to trust myth without looking for the real answer, which they can get quickly through multiple sources.

Type of residence. This independent variable was significantly correlated with the three HIV misconceptions. Therefore, there were different levels of HIV misconceptions between urban residences and rural residences. This finding supported by previous studies (Khanal et al., 2013 \& Oginni et al., 2017). However, the relationship between this independent variable with the dependent variables was different for each dependent variable. This study found that for the first misconception, respondents who live in urban areas were more likely to have this HIV misconception.

On the other hand, for the second and third HIV misconceptions, those who live in urban areas were less likely to have these two HIV misconceptions. It may happen since the gap between rural areas and urban locations in Indonesia is very high. Based on the Credit Suisse Research Institute (2019), the Gini ratio, which represents the inequality condition in Indonesia, was the third-highest in South East Asia by 83.3. There was a big 
Jurnal Kebijakan Pembangunan Daerah, Vol. 4 No. 2 , Desember 2020, Hal. 109 - 117 p-ISSN: 2597-4971, e-ISSN: 2685-0079

difference between the health facilities in big cities and rural areas. They are not only facilities for the health facilities, but also the supporting facilities that should be available to improve the health condition in all regions.

The wealth index. This independent variable only significantly associated with the third misconception about HIV. This is support by a finding from other studies (Khanal et al., 2013; Oginni et al., 2017 \& Oljira et al., 2013). The respondents with a higher index of wealth were less likely to have misconceptions about HIV than they who have a lower index of wealth. This condition may happen due to bias in the influence of wealth on HIV misconception knowledge, where wealth may be deluded by education and media exposure. People from higher wealth index may have better knowledge regarding HIV misconception through better educational attainment and higher ability to gain multiple sources of media exposure.

Educational attainment. This independent variable was significantly associated with HIV misconceptions. This is consistent with a finding from other studies (Agüero \& Bharadwaj, 2014; Khanal et al., 2013; Ochako et al., 2011; Oginni et al., 2017; \& Oljira et al., 2013). The respondents who have a higher degree of educational attainment were less likely to have misconceptions about HIV than they who have a lower degree of educational attainment. It may happen due to higher understanding from people with higher education regarding health issues, which include HIV topics. Higher educated people have the opportunity to gain broader knowledge and information, which may include HIV topics.

Moreover, higher education may be effected in more extensive interactions between people and their friends as they can make more friends with each stage of school. Through communication with their pairs or friends at different levels of school, they may gain more information and a better understanding of HIV. Higher education also may provide better facilities and even teachers who have more ability and knowledge to teach regarding HIV topics. Besides, a more upper school may invite a professional person from a specific field to strengthen student's knowledge about HIV.

The frequency of reading newspapers or magazines. This independent variable was positively correlated with the three HIV misconceptions, where those who have a higher frequency of reading newspapers or magazines were less likely to have the misconceptions about HIV. However, in Indonesia, there were only $12.2 \%$ of people read newspapers or magazines at least once a week.

The frequency of listening to the radio. This independent variable was positively correlated with the three HIV misconceptions, which means those who have a higher frequency of listening to the radio were less likely to have the misconceptions about HIV. However, in Indonesia, there were only $13.2 \%$ 
Jurnal Kebijakan Pembangunan Daerah, Vol. 4 No. 2 , Desember 2020, Hal. 109 - 117

p-ISSN: 2597-4971, e-ISSN: 2685-0079

of people listening to the radio at least once a week.

The frequency of watching television. This independent variable was positively correlated with the three HIV misconceptions, which means those who have a higher frequency of watching television were less likely to have the misconceptions about HIV. Gladly, in Indonesia, $82.6 \%$ of people watching television at least once a week.

The frequency of using the internet. This independent variable was only positively correlated with the third HIV misconception, which means those who have a higher frequency of using the internet were less likely to have the misconceptions about HIV. However, in Indonesia, only $43,1 \%$ of people were using the internet at least once a week.

In summary, media exposure was significantly associated with HIV misconceptions knowledge. This is consistent with the finding from other studies (Asaduzzaman et al., 2016; Khanal et al., 2013; \& Oljira et al., 2013). The respondents who have a higher frequency of using the media were less likely to have misconceptions about HIV than those who have a lower frequency of using the media. However, the biggest influence was from television since, in the Indonesian context, TV is more popular than any other media. The internet also very famous among Indonesian people, but so far, the internet in Indonesia tends to use more on social media rather than apply to increase people's knowledge.

\section{CONCLUSION}

In summary, the misconceptions about HIV in Indonesia were relatively high. Sociodemographic factors and media exposure significantly correlated with the high level of HIV misconceptions in Indonesia. The respondents who belong to the younger age group, living in urban areas, have a higher degree of education, and have higher exposure to media were less likely to have misconceptions about HIV. This result indicates that to reduce HIV misconceptions in Indonesia, the government should make a targeted intervention program.

\section{DAFTAR PUSTAKA}

Adi, G. N. (2019). "We had no choice" Surakarta school expels students with HIV_AIDS National - The Jakarta Post. The Jakarta Post.

Agüero, J. M., \& Bharadwaj, P. (2014). Do the more educated know more about health? Evidence from schooling and HIV knowledge in Zimbabwe. Economic Development and Cultural Change, 62(3), 489-517. https://doi.org/10.1086/675398

Asaduzzaman, M., Higuchi, M., Sarker, M. A. B., \& Hamajima, N. (2016). Awareness and knowledge of HIV/AIDS among married women in rural Bangladesh and exposure to media: A secondary data analysis of the 2011 Bangladesh demographic and health survey. Nagoya Journal of Medical Science, 78(1), 109-118. https://doi.org/10.18999/nagjms.78.1.109

Credit Suisse Research Institute. (2019). Global Wealth Databook 2019 - Credit Suisse, Research Institute (Issue October).

Fenny, A. P., Crentsil, A. O., \& Asuman, D. (2017). Determinants and Distribution of Comprehensive HIV/AIDS Knowledge in Ghana. Global Journal of Health Science, 9(12), 32. https://doi.org/10.5539/gjhs.v9n12p32 
Jurnal Kebijakan Pembangunan Daerah, Vol. 4 No. 2 , Desember 2020, Hal. 109 - 117 p-ISSN: 2597-4971, e-ISSN: 2685-0079

Glick, P., Randriamamonjy, J., \& Sahn, D. E. (2009). Determinants of HIV knowledge and condom use among women in Madagascar: An analysis using matched household and community data. African Development Review, 21(1), 147-179. https://doi.org/10.1111/j.14678268.2009.00206.x

Hossain, M., Mani, K. K. C., Sidik, S. M., Shahar, H. K., \& Islam, R. (2014). Knowledge and awareness about STDs among women in Bangladesh. BMC Public Health, 14(1), 1-7. https://doi.org/10.1186/1471-2458-14-775

Jha, P. K., Narayan, P., Nair, S., Ganju, D., Sahu, D., \& Pandey, A. (2015). An Assessment of Comprehensive Knowledge of HIV/AIDS among Slum and Non-Slum Populations in Delhi, India. Open Journal of Preventive Medicine, 259-268. https://doi.org/10.4236/ojpm.2015.56029

Kejela, G. (2015). Comprehensive HIV/AIDS Knowledge Level among Out-of-School Youths in Wayu Tuka District, Western Ethiopia. European Journal of Preventive Medicine, 3(1), 11. https://doi.org/10.11648/j.ejpm.20150301.1 3

Khanal, V., Adhikari, M., \& Karkee, R. (2013). Social determinants of poor knowledge on HIV among nepalese males: Findings from national survey 2011. Journal of Community Health, 38(6), 1147-1156. https://doi.org/10.1007/s10900-013-9727-4

Kiderlen, T. R., Conteh, M., Roll, S., Seeling, S., \& Weinmann, S. (2013). Cross-Sectional Study Assessing HIV Related Knowledge, Attitudes and Behavior in Namibian Public Sector Employees in Capital and Regional Settings. PLoS ONE, 8(9), 1-8. https://doi.org/10.1371/journal.pone.007559 3

Mwamwenda, T. S. (2014). African University students' knowledge of HIV/AIDS and mosquito bites. Mediterranean Journal of Social Sciences, 5(20), 1847-1853. https://doi.org/10.5901/mjss.2014.v5n20p18 47

National Population and Family Planning Board (BKKBN), Statistics Indonesia (BPS), Ministry of Health (Kemenkes), and I. (2017). Indonesia 2017 DHS.
Nubed, C. K., \& Akoachere, J. F. T. K. (2016). Knowledge, attitudes and practices regarding HIV/AIDS among senior secondary school students in Fako Division, South West Region, Cameroon. BMC Public Health, 16(1), 1-11. https://doi.org/10.1186/s12889016-3516-9

Ochako, R., Ulwodi, D., Njagi, P., Kimetu, S., \& Onyango, A. (2011). Trends and determinants of Comprehensive HIV and AIDS knowledge among urban young women in Kenya. AIDS Research and Therapy, 8(1), 11. https://doi.org/10.1186/1742-6405-8-11

Odimegwu, C. O., Alabi, O., De Wet, N., \& Akinyemi, J. O. (2018). Ethnic heterogeneity in the determinants of HIV/AIDS stigma and discrimination among Nigeria women. BMC Public Health, 18(1), 1-13. https://doi.org/10.1186/s12889-018-5668-2

Oginni, A. B., Adebajo, S. B., \& Ahonsi, B. A. (2017). Trends and determinants of comprehensive knowledge of HIV among adolescents and young adults in Nigeria: 2003 - 2013. African Journal of Reproductive Health, 21(2), 26-34. https://doi.org/10.29063/ajrh2017/v21i2.4

Oljira, L., Berhane, Y., \& Worku, A. (2013). Assessment of comprehensive HIV/AIDS knowledge level among in-school adolescents in eastern Ethiopia. Journal of the International AIDS Society, 16, 11-16. https://doi.org/10.7448/IAS.16.1.17349

Owusu, S. (2018). University of Ghana http://ugspace.ug.edu.gh UNIVERSITY OF GHANA SCHOOL OF PUBLIC HEALTH TRENDS AND DETERMINANTS OF COMPREHENSIVE KNOWLEDGE OF HIV / AIDS AMONG GHANAIANS BASED ON GHANA DEMOGRAPHIC HEALTH SURVEYS , 1998-2014 . BY STEPHEN OWUSU ( ID NO . 10 (Issue 10637429).

Sheikh, M. T., Uddin, M. N., \& Khan, J. R. (2017). A comprehensive analysis of trends and determinants of HIV/AIDS knowledge among the Bangladeshi women based on Bangladesh Demographic and Health Surveys, 2007-2014. Archives of Public Health, 75(1), 1-11. https://doi.org/10.1186/s13690-017-0228-2 
Shokoohi, M., Karamouzian, M., Mirzazadeh, A., Haghdoost, A., Rafierad, A. A., Sedaghat, A., \& Sharifi, H. (2016). HIV knowledge, attitudes, and practices of young people in Iran: Findings of a national population-based survey in 2013. PLoS ONE, 11(9), 1-16. https://doi.org/10.1371/journal.pone.016184 9

Smith, G., Kippax, S., Aggleton, P., \& Tyrer, P. (2003). HIV/AIDS School-based Education in Selected Asia-Pacific Countries. Sex Education, 3(1), 3-21. https://doi.org/10.1080/1468181032000052 126

Teshome, R., \& Youjie, W. (2016). Comparison and Association of Comprehensive HIV/AIDS Knowledge and Attitude towards people Living with HIV/AIDS among Women Aged 15- 49 in Three East African Countries: Burundi, Ethiopia and Kenya. Journal of AIDS \& Clinical Research, 07(04), 4-11. https://doi.org/10.4172/21556113.1000559

UNAIDS. (2014). To help end the AIDS epidemic. United Nations, 40. http://www.unaids.org/sites/default/files/me dia_asset/90-90-90_en.pdf

Yaya, S., Bishwajit, G., Danhoundo, G., \& Seydou, I. (2016). Extent of Knowledge about HIV and Its Determinants among Men in Bangladesh. Frontiers in Public Health, 4(November).

https://doi.org/10.3389/fpubh.2016.00246

Yaya, S., Bishwajit, G., Danhoundo, G., Shah, V., \& Ekholuenetale, M. (2016). Trends and determinants of HIV/AIDS knowledge among women in Bangladesh. BMC Public Health, 16(1), 1-10. https://doi.org/10.1186/s12889-016-3512-0 